\title{
Prediction of NDF degradation characteristics of grass and grass/clover forages based on laboratory methods*
}

\author{
V. Koukolová ${ }^{1,2}$, M.R. Weisbjerg ${ }^{1,3}$, T. Hvelplund ${ }^{1}$, P. Lund ${ }^{1}$ \\ and B. Cermák ${ }^{2}$
}

\author{
${ }^{1}$ Danish Institute of Agricultural Sciences, Department of Animal Nutrition and Physiology \\ P.O. Box 50, DK-8830 Tjele, Denmark \\ ${ }^{2}$ University of South Bohemia, Faculty of Agriculture, Department of Genetics, \\ Breeding and Animal Nutrition \\ Studentská 13, 37005 České Budějovice, Czech Republic *
}

(Received 26 January 2004; revised version 28 June 2004; accepted 25 October 2004)

\begin{abstract}
The degradation profiles of neutral detergent fibre (NDF) for typical Danish forages ( 25 grass and grass/clover samples) were evaluated using rumen nylon bag incubations.

In vitro digestibility of organic matter $(\mathrm{OM})$ and NDF was performed by two different standard laboratory methods, one based on Tilley and Terry rumen fluid (T and T) and one on enzymes (ENZ). Concentrations of NDF, acid detergent fibre (ADF) and acid detergent lignin (ADL), ash and crude protein $(\mathrm{CP})$ in feeds were determined. The ability to predict in situ potential NDF degradability and in situ fractional rate of NDF degradation based on in vitro digestibilities and on chemical analyses was tested using multiple regression analysis.

A considerable variation was found in NDF degradation between samples. The indigestible NDF (INDF) proportion was determined after $504 \mathrm{~h}$ in situ incubation and ranged from 0.047 to 0.246 of NDF. Fractional rate of NDF degradation (c) varied from 0.022 to 0.150 per hour. The potential degradable NDF fraction (b) showed high correlation with ADL content and ADL/NDF ratio. Fractional rate of degradation (c) showed the highest correlation with in vitro enzymatic NDF digestibility $\left(\mathrm{ENZ}_{\mathrm{NDF}}\right)$ and NDF and ADL content. This shows that potential degradability of NDF is mostly correlated to lignification of fibre, whereas fractional rate of degradation is mostly correlated to digestibility.

It was possible to describe 0.87 of the variation in the potentially degradable NDF fraction (b) and 0.83 of the variation in fractional rate of degradation (c) using all available information on the feeds. Equations based on in vitro OM digestibility and chemical analyses described 0.83 and 0.85 of the
\end{abstract}

\footnotetext{
"Supported by the Danish Cattle Federation

${ }^{3}$ Corresponding author: e-mail: Martin.Weisbjerg@agrsci.dk
} 
variation in $\mathrm{b}$ and $\mathrm{c}$, respectively, and cquations based only on NDF content and calculated in vivo OM digestibility (sheep) were able to describe approximately 0.80 of the variation in $b$ and $c$.

KEY WORDS: DNDF, effective degradability, fibre, forage, INDF, NDF, potential degradability, rate of degradation

\section{INTRODUCTION}

The nutritive value of forages for ruminants highly depends on the ratio between cell content and cell walls and on the ability of the rumen microorganisms to degrade the plant cell walls (Waldo, 1986) as cell content has a high digestibility. The primary function of the NDF fraction in ruminant diets is to provide energy for microbial synthesis and to the animal via short chain fatty acids produced during fermentation, but also to secure rumen function and animal health by adding structural value to the diet (Mertens, 1994). The utilization of the fibre fraction in ruminant diets varies highly within and between forage types and is highly influenced by associative effects (Stensig and Robinson, 1997).

Analysis of the content of fibre (cell wall constituents) in ruminant feeds is based on the NDF analysis (Van Soest et al., 1991). The detergent system is a rapid procedure for determining the insoluble cell wall matrix and estimating its major subcomponents, as hemicellulose, cellulose and lignin can be determined from NDF, ADF and ADL analysis (Van Soest, 1994).

Based on either long time in vitro or in situ incubations, the NDF fraction can be divided into potentially digestible NDF (DNDF) and indigestible NDF (INDF) (Allen and Mertens, 1988).

Degradation rate of INDF is zero and is therefore defined as an "ideal nutritional entity" (Ellis et al., 1999). Lignin is often regarded as the primary factor limiting digestibility of forages (Besle et al., 1994; Van Soest, 1994) and thereby the magnitude of INDF. Lignin is indigestible and from its interaction with other cell wall constituents it reduces the proportion of potentially digestible fibre (Traxler et al., 1998). The estimation of INDF is critical for an accurate description of digestion kinetics, although the INDF fraction is not related to the animals capability of digestion, but is an intrinsic characteristic of the feed (Mertens, 1993).

Potential degradability and rate of degradation of NDF are key values in new feed evaluation systems. Therefore laboratory methods (chemical analysis and in vitro digestibilities) need to be developed for prediction of NDF degradation characteristics, as in situ techniques are resource demanding and require access to cannulated animals (Madsen and Hvelplund, 1994) and therefore not acceptable as routine methods in feed evaluation. Potential degradability can also be determined based on long term in vitro incubations. Mertens (1993) recommends in vitro compared to in situ methods, because fermentation conditions can be optimized, 
contamination due to influx of fine particles from the rumen content is eliminated and particle loss from bags avoided. However, the in situ method is preferred by most researches, as it is believed to be closer to actual in vivo conditions, especially when an effective degradability is calculated from the degradation profile weighted with a fractional passage rate. However, for routine analysis in practical agriculture the in situ method is too laborious.

The objective of the present study was to develop equations to predict NDF degradation characteristics based on laboratory methods (Tilley and Terry in vitro digestibility, enzymatic in vitro digestibility and concentration of NDF, ADF and ADL in the feed).

\section{MATERIAL AND METHODS}

Twenty-five samples of grass and grass/clover forages, of which 13 were silages, were selected from a bank of samples previously examined at our laboratory for protein and dry matter (DM) nylon bag degradability. Grass was mainly ryegrass (Lolium perenne) and clover was mainly white clover (Trifolium repens). Samples were selected to cover as large a variation as possible in DM degradability after $96 \mathrm{~h}$ rumen incubation (from 0.794 to 0.980 ), assuming that this selection would give a similar variation in NDF degradability. Samples had been freeze dried and milled through a $1.5 \mathrm{~mm}$ screen before the previous examinations, and since then stored in a deep freezer.

Nylon bag NDF degradability (pore size $37 \mu \mathrm{m}$ ) was measured after $0,2,4,8$, $16,24,48,96,168$ and $504 \mathrm{~h}$ incubation according to Hvelplund and Weisbjerg (2000). Measurements were repeated in three dry Holstein cows fitted with a rumen cannula. The cows were fed twice daily, and had free access to drinking water. The feed ration was composed of grass hay $(5.4 \mathrm{~kg} / \mathrm{day})$ and concentrate mixture $(2.6 \mathrm{~kg} / \mathrm{day})$. Composition of concentrate mixture $(\mathrm{g} / \mathrm{kg}$ of mixture) was soyabean meal (100), barley (420), oat (420), rapeseed meal (30) and sugar beet molasses (30). Furthermore, cows were fed granulated minerals ( $200 \mathrm{~g} /$ day) and a vitamin mixture ( $150 \mathrm{~g}$ per week).

To give proper amounts of residues for Ankom fibre filter bag analysis the amount of sample weighed into the nylon bags was: $0.50 \mathrm{~g}$ for 0,2 and $4 \mathrm{~h}$ incubations; $0.75 \mathrm{~g}$ for $8 \mathrm{~h}$ incubation and $1.00 \mathrm{~g}$ for $16,24,48,96,168$ and $504 \mathrm{~h}$ incubations, accepting that this will result in variable initial sample to bag surface ratio. After incubation, residual NDF in nylon bag residues was determined using an Ankom fibre analyser (Anonymous, 1998). Sodium sulphite and heat stable $\alpha$-amylase (Anonymous, 1998) were used to dissolve protein and starch, and ash free NDF residues were subsequently determined by overnight drying at $100^{\circ} \mathrm{C}$ and subsequent combustion at $525^{\circ} \mathrm{C}$. 
Ash-free NDF, ADF and ADL were determined using a Fibertec analyser (Fibertec System M). NDF was determined according to Van Soest et al. (1991). An overnight pretreatment with $\alpha$-amylase (A6380, Sigma) at $38^{\circ} \mathrm{C}$ according to Ferreira et al. (1983) was applied and subsequent followed by addition of sodium sulphite and a heat stable $\alpha$-amylase (Termamyl, Novo Nordisk, Denmark) during NDF boiling. ADF and ADL were analysed according to Van Soest et al. (1991). $\mathrm{CP}$ was analysed according to the Kjeldahl method (AOAC, 1990). Ash was determined after combustion at $525^{\circ} \mathrm{C}(\mathrm{AOAC}, 1990)$.

For in vitro $\mathrm{OM}$ digestibility two standard procedures were used. In the in vitro rumen fluid method ( $\mathrm{T}$ and $\mathrm{T}$ ) the feed samples were incubated for $48 \mathrm{~h}$ in buffered rumen fluid followed by $48 \mathrm{~h}$ in pepsin- $\mathrm{HCl}$ before determining the insoluble organic residue as difference in dry residue before and after combustion. The procedure was according to Tilley and Terry (1963) except for the determination of OM instead of DM residue. In the in vitro enzymatic method (ENZ), samples were first treated with pepsin- $\mathrm{HCl}$ in order to dissolve the protein. Then the solution was heated to $80^{\circ} \mathrm{C}$. After washing, the samples were incubated with an enzyme-mix (Celluclast, NOVO; Novozym 188, NOVO; Gamanase, NOVO; Viscozym, NOVO; amyloglycosidase, Megazyme), which dissolve digestible cell wall carbohydrates and eventual starch. The nonsolubilized residues were subsequently washed with hot water and then with acetone in order to extract any fat before determining the insoluble organic residue as difference in residue before and after combustion (Weisbjerg and Hvelplund, 1993). In vitro NDF digestibility ( $\mathrm{T}$ and $\mathrm{T}_{\mathrm{NDF}} ; \mathrm{ENZ}_{\mathrm{NDF}}$ ) was determinated using the above mentioned methods for in vitro OM digestibility ( $\mathrm{T}$ and $\mathrm{T}$ and $\mathrm{ENZ}$ ), but with modifications. For the $\mathrm{T}$ and $\mathrm{T}$ method ( $\mathrm{T}$ and $T_{\text {NDF }}$ ) the rumen fluid incubation was followed by transfer of residues to fibretec crucibles using boiling water to arrest any microbial activity. NDF analyses were performed on Fibertec analyser (Fibertec System M) according to the standard procedure mentioned above, but without the pre-treatment with $\alpha$-amylase. For the ENZ method $\left(\mathrm{ENZ}_{\mathrm{NDF}}\right)$, the first washing with boiling water after incubation was followed by transfer of residues to fibretec crucibles for NDF determination as described above for $\mathrm{T}$ and $\mathrm{T}_{\mathrm{VIPF}}$

In vivo sheep OM digestibility based on $\mathrm{ENZ}$ analysis was calculated according to Søegaard et al. (2001): in vivo OM digestibility $=0.260+0.658 \times \mathrm{ENZ}$. DNDF was estimated as the proportion of NDF degraded after 21 days $(504 \mathrm{~h})$ rumen incubation and was calculated as 1 - INDF. Modified in vitro OM digestibilities $\left(\mathrm{ENZ}_{\text {mod }}\right.$ and $\mathrm{T}$ and $\mathrm{T}_{\text {mod }}$ ) were calculated using the NDF residue as organic residue calculated as follows: (OM weighed out-NDF residue)/(OM weighed out).

For calculation of NDF nylon bag degradabilities, NDF residues at the respective incubation times were related to the NDF residue at zero $h$ incubation, where bags were not rumen incubated, but only washed. Obtained 
values are therefore corrected for eventually initial particle losses (Hvelplund and Weisbjerg, 2000). However, this is based on the assumption that NDF in small particles lost were representative for all NDF. NDF degradation profiles were calculated using equations both with lag time and without lag time. The soluble a fraction was omitted from the equations, as NDF per definition is insoluble, and as the calculation of degradability included correction of eventual initial particle losses. NDF degradation profiles were calculated using results from incubation times of $2,4,8,24,48,96$ and $168 \mathrm{~h}$ according to the following equations:

1. with lag time (McDonald, 1981)

$$
\operatorname{Deg}(t)=b \times\left(1-\mathrm{e}^{-c(t-1)}\right)
$$

2. without lag time (Ørskov and McDonald, 1979)

$$
\operatorname{Deg}(t)=b \times\left(1-\mathrm{e}^{-c t}\right)
$$

Effective ruminal degradation of NDF was calculated using the models shown below and assuming a fractional passage rate of 0.02 per $h$. These models were used to get values for ranking of the samples, knowing that the simple assumptions on passage, which do not take into account selective retention of newly ingested NDF in the rumen, will underestimate in vivo NDF digestibility:

1. with lag time (McDonald, 1981)

$$
\mathrm{ED}=\mathrm{b} \times(\mathrm{c} /(\mathrm{c}+\mathrm{k})) \times \mathrm{e}^{\left(-\mathrm{k}^{*} t \mathrm{t}\right)}
$$

2. without lag time (Ørskov and McDonald, 1979)

$$
\mathrm{ED}=\mathrm{b} \times(\mathrm{c} /(\mathrm{c}+\mathrm{k}))
$$

where:

Deg $(t)=$ fraction of NDF degraded at time $t$ of incubation

$\mathrm{ED}=$ effective ruminal degradation of NDF fraction

$\mathrm{b}=$ degradable NDF fraction

$c=$ fractional rate of degradation of fraction $b\left(h^{-1}\right)$

$\mathrm{k}=$ fractional passage rate from the rumen $\left(\mathrm{h}^{-1}\right)$

lt $=$ lag time $(\mathrm{h})$

Estimates of b, c and lt were calculated using a Non Linear Model PROC NLIN (SAS Institute, 2000). Correlation coefficients between variables were computed using PROC CORR (SAS Institute, 2000). Multiple regression equations for prediction of degradation parameters were estimated using PROC STEPWISE (SAS Institute, 2000). Overparameterization was avoided by the restrictions that parameters should be significant at 0.15 levels and by using Mallows $\mathrm{C}_{\mathrm{p}}$ for model selection (SAS Institute, 2000). The prediction ability of 
the estimated models was tested in a cross-validation using the PRESS function in PROC REG (SAS Institute, 2000). PRESS is weighted with n-p as for RMSE ( $p$ is number of parameters in the equation, $n$ number of observations), PRESS is the prediction error in a cross-validation where observations are left out one by one, and the model fitted without the observation is used to predict the observation.

\section{RESULTS}

The chemical composition and in vitro digestibility values of the experimental feeds are shown in Table 1 . The CP content varied from 94 to $289 \mathrm{~g} / \mathrm{kg} \mathrm{DM}$. With respect to feed type the CP varied from 145 to $289 \mathrm{~g} / \mathrm{kg} \mathrm{DM}$ for fresh forages and from 94 to $207 \mathrm{~g} / \mathrm{kg}$ DM for ensiled forages. NDF content ranged from 229 to $577 \mathrm{~g} / \mathrm{kg}$ DM. As expected, the NDF content was higher in late cut $(564 \mathrm{~g} / \mathrm{kg}$ $\mathrm{DM}$, silage 25) than in silage from grass/clover cut 3 weeks before $(434 \mathrm{~g} / \mathrm{kg} \mathrm{DM}$, silage 24). ADF and ADL concentration in DM varied from 149 to 374 and from 8 to $44 \mathrm{~g} / \mathrm{kg}$ DM, respectively.

In vitro $\mathrm{T}$ and $\mathrm{T} \mathrm{OM}$ digestibility ranged from 0.478 to 0.840 and $\mathrm{ENZ}$ from 0.565 to 0.911 . In vitro NDF digestibility ranged from 0.459 to 0.872 and from 0.389 to 0.883 using the $\mathrm{T}$ and $\mathrm{T}_{\mathrm{NDF}}$ and $\mathrm{ENZ} \mathrm{NDF}_{\mathrm{ND}}$, respectively. $\mathrm{ENZ}_{\text {mod }}$ and $\mathrm{T}$ and $\mathrm{T}_{\text {mod }}$ were highly correlated to OM digestibility determined using either ENZ $(\mathrm{r}=0.99)$ or $\mathrm{T}$ and $\mathrm{T}(\mathrm{r}=0.98)$.

A wide variation in NDF degradability at different incubation times was found for the 25 forage samples (Figure 1). The NDF degradation after $8 \mathrm{~h}$ incubation varied from 0.121 to 0.723 and degradation after $96 \mathrm{~h}$ varied from 0.666 to 0.946 . The proportion of NDF that is indigestible (INDF) ranged from 0.047 to 0.246 of NDF. To determine INDF long incubations seems necessary, as degradation continued after one week of incubation ( $168 \mathrm{~h}$ ) and the increase from one week to three weeks $(504 \mathrm{~h})$ incubation was on an average 0.016 with a variation from 0 to 0.061 (results not shown).

Calculated degradation parameters for NDF are shown in Table 2 together with values for effective ruminal degradation (ED) of NDF calculated with a fractional passage rate of 0.02 per $h$. Data from $16 \mathrm{~h}$ incubations were excluded due to lower degradabilities for these incubations than expected from the profile for the rest of the incubations (Figure 1). $504 \mathrm{~h}$ incubation data were also excluded, because inclusion of these data resulted in larger residuals when fitting the degradation profiles. The lag time was generally short. On average lag time was $1 \mathrm{~h}$ and varied from zero to $4.5 \mathrm{~h}$. As lag times were short, degradation parameters were also calculated with a simpler model without lag time. Due to the short lag times, inclusion of lag time in the model had only minor effect on 


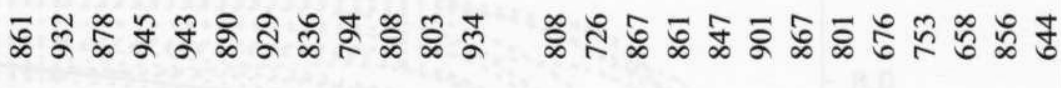

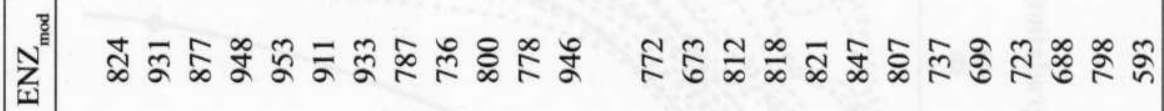

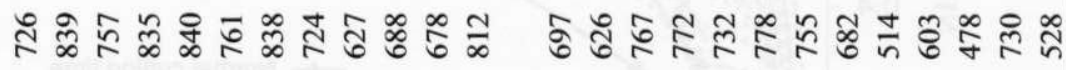

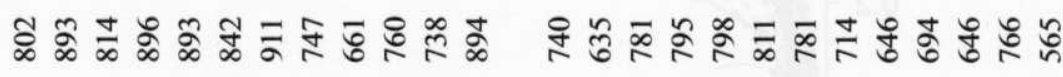

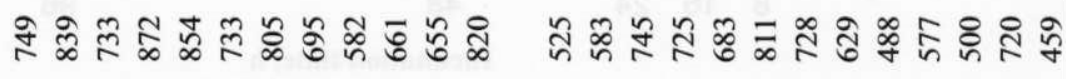

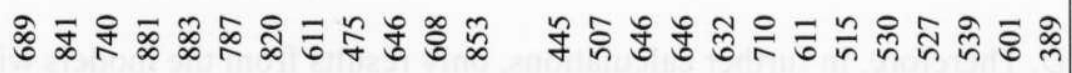

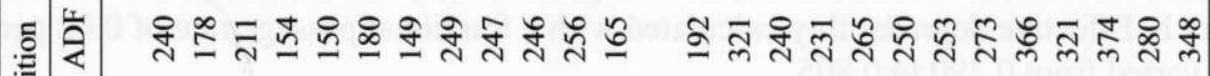

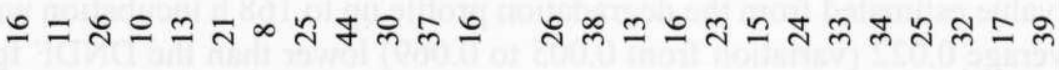

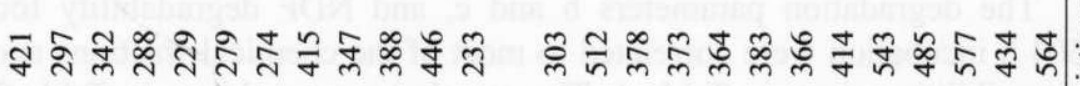

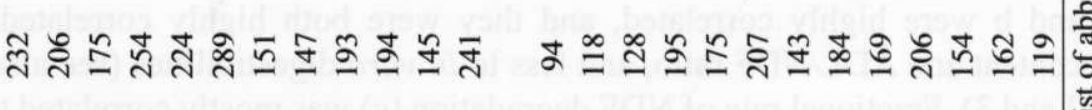

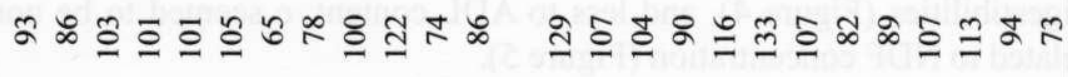

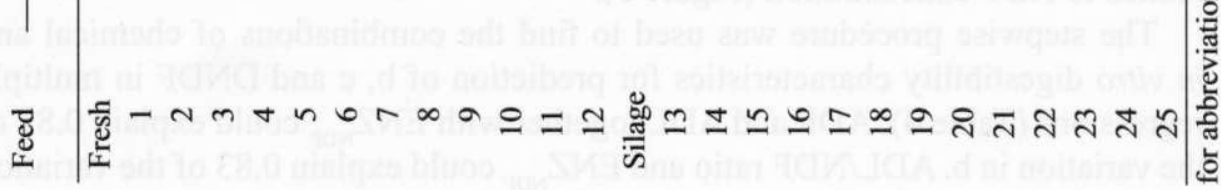




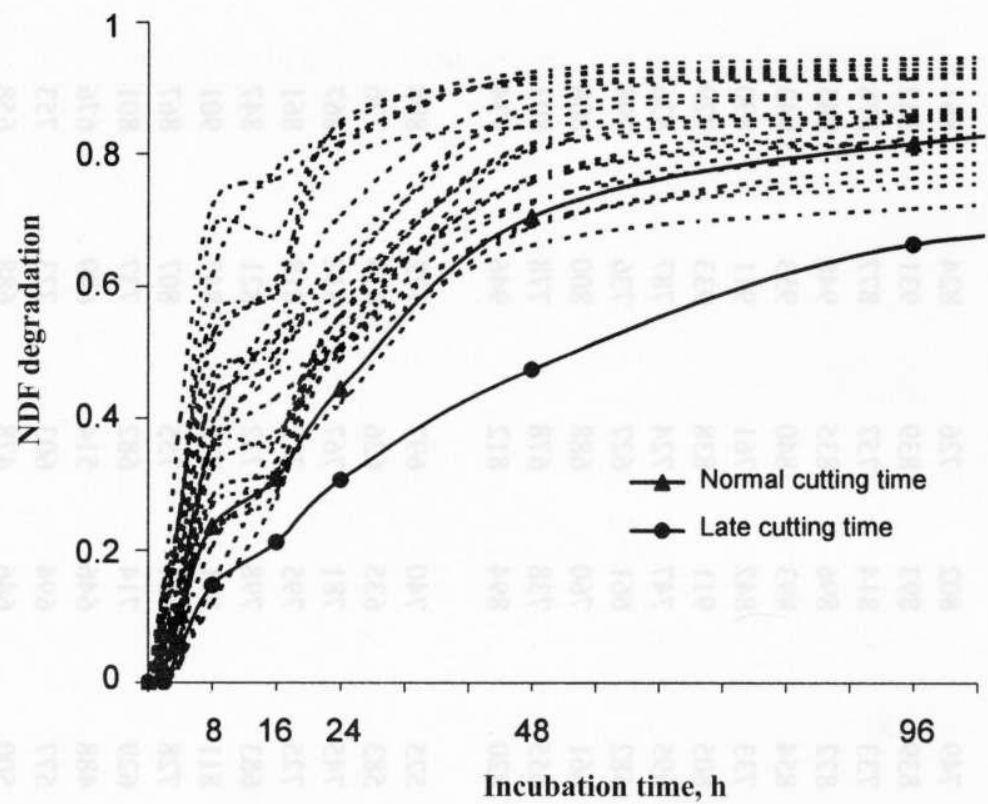

Figure 1. NDF degradation profiles based on in situ incubation data. The two full line curves show NDF degradability of silage samples from the same sward varying 3 weeks in cutting time

ED. Therefore, in further calculations, only results from the models without lag time were used.

The potentially degradable NDF fraction (b) varied from 0.725 to 0.939 . The $\mathrm{b}$ value estimated from the degradation profile up to $168 \mathrm{~h}$ incubation was then on average 0.022 (variation from 0.005 to 0.069 ) lower than the DNDF found after $504 \mathrm{~h}$ incubation. The fractional rate of degradation (c) varied from 0.022 to 0.150 per h. Effective degradability calculated with a fractional passage rate of 0.02 per $\mathrm{h}$ varied from 0.390 to 0.805 .

The degradation parameters $\mathrm{b}$ and $\mathrm{c}$, and NDF degradability found after $504 \mathrm{~h}$ incubation were correlated to most of the chemical fractions and in vitro digestibilities given in Table 1. The correlations are shown in Table 3. DNDF and $b$ were highly correlated, and they were both highly correlated to ADL content and ADL/NDF ratio, and less to in vitro digestibilities (see also Figures 2 and 3). Fractional rate of NDF degradation (c) was mostly correlated to in vitro digestibilities (Figure 4), and less to ADL content. c seemed to be nonlinearly related to NDF concentration (Figure 5).

The stepwise procedure was used to find the combinations of chemical and in vitro digestibility characteristics for prediction of $\mathrm{b}, \mathrm{c}$ and DNDF in multiple regressions (Table 4). ADF and ADL together with $\mathrm{ENZ}_{\mathrm{NDF}}$ could explain 0.87 of the variation in $\mathrm{b}$. $\mathrm{ADL} / \mathrm{NDF}$ ratio and $\mathrm{ENZ}_{\mathrm{NDF}}$ could explain 0.83 of the variation 
TABLE 2

NDF degradability characteristics of fresh and ensiled grass and grass/clover

\begin{tabular}{|c|c|c|c|c|c|c|c|c|}
\hline \multirow{2}{*}{ Feed } & \multicolumn{4}{|c|}{ Without lag time } & \multicolumn{4}{|c|}{ With lag time ${ }^{4}$} \\
\hline & b & $c\left(h^{-1}\right)$ & $\mathrm{ED}^{1}$ & $\mathrm{DNDF}^{2}$ & $\mathrm{lt}^{3}(\mathrm{~h})$ & b & $C\left(h^{-i}\right)$ & $\mathrm{ED}^{\prime}$ \\
\hline \multicolumn{9}{|l|}{ Fresh } \\
\hline 1 & 0.889 & 0.065 & 0.680 & 0.919 & & & & \\
\hline 2 & 0.935 & 0.083 & 0.753 & 0.941 & 1.8 & 0.919 & 0.122 & 0.762 \\
\hline 3 & 0.885 & 0.075 & 0.697 & 0.907 & & & & \\
\hline 4 & 0.932 & 0.106 & 0.785 & 0.953 & 0.9 & 0.924 & 0.131 & 0.788 \\
\hline 5 & 0.939 & 0.118 & 0.803 & 0.951 & 1.1 & 0.929 & 0.161 & 0.807 \\
\hline 6 & 0.869 & 0.103 & 0.728 & 0.893 & 1.3 & 0.857 & 0.145 & 0.733 \\
\hline 7 & 0.934 & 0.087 & 0.759 & 0.942 & 0.9 & 0.926 & 0.104 & 0.763 \\
\hline 8 & 0.862 & 0.060 & 0.648 & 0.893 & & & & \\
\hline 9 & 0.725 & 0.056 & 0.535 & 0.754 & & & & \\
\hline 10 & 0.774 & 0.053 & 0.561 & 0.809 & & & & \\
\hline 11 & 0.823 & 0.045 & 0.572 & 0.850 & 0.8 & 0.817 & 0.050 & 0.573 \\
\hline 12 & 0.912 & 0.150 & 0.805 & 0.934 & 1.2 & 0.901 & 0.224 & 0.807 \\
\hline \multicolumn{9}{|c|}{ Silage } \\
\hline 13 & 0.775 & 0.041 & 0.520 & 0.811 & & & & \\
\hline 14 & 0.828 & 0.053 & 0.602 & 0.867 & & & & \\
\hline 15 & 0.932 & 0.049 & 0.660 & 0.937 & 1.5 & 0.918 & 0.059 & 0.665 \\
\hline 16 & 0.883 & 0.048 & 0.625 & 0.900 & & & & \\
\hline 17 & 0.876 & 0.047 & 0.612 & 0.889 & 1.3 & 0.865 & 0.054 & 0.616 \\
\hline 18 & 0.932 & 0.062 & 0.704 & 0.950 & 1.2 & 0.919 & 0.075 & 0.709 \\
\hline 19 & 0.851 & 0.041 & 0.571 & 0.866 & 0.7 & 0.845 & 0.044 & 0.572 \\
\hline 20 & 0.807 & 0.040 & 0.538 & 0.834 & 1.3 & 0.797 & 0.046 & 0.540 \\
\hline 21 & 0.882 & 0.031 & 0.538 & 0.896 & 4.5 & 0.852 & 0.045 & 0.539 \\
\hline 22 & 0.893 & 0.034 & 0.560 & 0.910 & 3.5 & 0.868 & 0.046 & 0.564 \\
\hline 23 & 0.889 & 0.038 & 0.582 & 0.905 & 2.0 & 0.874 & 0.046 & 0.583 \\
\hline 24 & 0.870 & 0.033 & 0.539 & 0.895 & 0.3 & 0.867 & 0.033 & 0.539 \\
\hline 25 & 0.738 & 0.022 & 0.390 & 0.776 & 0.7 & 0.733 & 0.023 & 0.390 \\
\hline
\end{tabular}

' effective ruminal degradation of NDF fraction assuming the fractional rate of passage to be $0.02 \mathrm{~h}^{-1}$

${ }^{2} \mathrm{NDF}$ degradability after $504 \mathrm{~h}$ in situ incubation

${ }^{3}$ lag time

${ }^{4}$ results not shown for samples when estimated lag time was zero

in c. $\mathrm{ADF}, \mathrm{ADL}, \mathrm{ENZ} \mathrm{mod}_{\mathrm{m}}$ and $\mathrm{NDF} \times \mathrm{NDF}$ content could explain 0.88 of the variation in DNDF.

Regression analyses were also performed where all measures except in vitro NDF digestibilites were included. ADF, ADL and ENZ $\times$ ENZ could explain 0.83 of the variation in parameter $\mathrm{b}$. ADL/NDF ratio, ENZ, ENZ $\times \mathrm{ENZ}$ and content of CP could explain 0.85 of variations in $\mathrm{c}$. ADL, ENZ and NDF $\times$ NDF could explain 0.83 of the variation in DNDF. 
TABLE 3

Correlation between NDF degradation characteristics $\left(b^{1}, c^{2}\right.$ and DNDF $\left.{ }^{3}\right)$ and chemical fractions and in vitro digestibilities

\begin{tabular}{|c|c|c|c|}
\hline Parameter & $b$ & c & DNDF \\
\hline \multicolumn{4}{|l|}{$\mathrm{b}$} \\
\hline c & $0.49^{\circ}$ & & \\
\hline DNDF & $0.99^{\circ}$ & $0.52^{*}$ & \\
\hline $\mathrm{NDF}^{4}$ & -0.34 & $-0.78^{\circ}$ & -0.33 \\
\hline $\mathrm{ADF}^{4}$ & -0.37 & $-0.78^{\circ}$ & -0.37 \\
\hline $\mathrm{ADL}^{4}$ & $-0.82^{\circ}$ & $-0.55^{*}$ & $-0.82^{\circ}$ \\
\hline $\mathrm{ADL} / \mathrm{NDF}^{5}$ & $-0.80^{\circ}$ & -0.13 & $-0.80^{\circ}$ \\
\hline $\mathrm{CP}^{4}$ & 0.39 & $0.66^{*}$ & $0.41^{\circ}$ \\
\hline$T$ and $T_{N D F}{ }^{6}$ & $0.69^{\circ}$ & $0.73^{*}$ & $0.70^{\circ}$ \\
\hline $\mathrm{ENZ}_{\mathrm{NDF}}^{{ }^{\mathrm{NDF}}}$ & $0.75^{\circ}$ & $0.86^{*}$ & $0.76^{\circ}$ \\
\hline $\mathrm{T}$ and $\mathrm{T}^{6}$ & $0.55^{\circ}$ & $0.68^{*}$ & $0.55^{\circ}$ \\
\hline $\mathrm{ENZ}^{6}$ & $0.69^{\circ}$ & $0.77^{*}$ & $0.68^{\circ}$ \\
\hline $\mathrm{T}$ and $\mathrm{T}{ }^{6}$ & $0.58^{\circ}$ & $0.72^{\circ}$ & $0.58^{\circ}$ \\
\hline $\mathrm{ENZ}_{\bmod }^{6}$ & $0.66^{*}$ & $0.83^{*}$ & $0.66^{\circ}$ \\
\hline
\end{tabular}

'potentially degradable fraction

${ }^{2}$ fractional rate of degradation $\left(\mathrm{h}^{-1}\right)$

${ }^{3}$ NDF degradability after $504 \mathrm{~h}$ in situ incubation

${ }^{4} \mathrm{~g} / \mathrm{kg}$ of DM

${ }^{5} \mathrm{ADL} / \mathrm{NDF}$ ratio

${ }^{6}$ in vitro $\mathrm{OM}$ and NDF digestibilities, see list of abbreviations

"significance was declared when $\mathrm{P}<0.05$

TABLE 4

Multiple regression equations for prediction of parameters of NDF degradation $\left(b^{1}, c^{2}\right.$ and $\left.D_{N D F}\right)$. Units for chemical analysis are $\mathrm{kg} / \mathrm{kg}$ DM and for digestibilities $\mathrm{kg} / \mathrm{kg}$

\begin{tabular}{llrll}
\hline Y variable & $\mathrm{X}$ variables and regression parameter estimates & $\mathrm{R}^{2}$ & $\mathrm{RMSE}^{4}$ & $\mathrm{PRESS}^{5}$ \\
\hline \multicolumn{2}{l}{ Based on all analyses } & & & \\
$\mathrm{b}$ & $0.607+0.632 \mathrm{ADF}-4.29 \mathrm{ADL}+0.318 \mathrm{ENZ}_{\mathrm{NDF}}$ & 0.87 & 0.024 & 0.029 \\
$\mathrm{c}$ & $-0.116+0.512 \mathrm{ADL} / \mathrm{NDF}+0.227 \mathrm{ENZ}_{\mathrm{NDF}}$ & 0.83 & 0.013 & 0.016 \\
$\mathrm{DNDF}$ & $0.253+0.402 \mathrm{ADF}-3.19 \mathrm{ADL}+0.672 \mathrm{ENZ}_{\text {mod. }}+0.434(\mathrm{NDF} \times \mathrm{NDF})$ & 0.88 & 0.021 & 0.025
\end{tabular}

Based on in vitro $\mathrm{OM}$ digestibility and chemical analyses

$\begin{array}{llrrr}\text { b } & 0.404+0.943 \mathrm{ADF}-3.06 \mathrm{ADL}+0.551(\mathrm{ENZ} \times \mathrm{ENZ}) & 0.83 & 0.027 & 0.032 \\ \text { c } & 0.458+0.430 \mathrm{ADL} / \mathrm{NDF}-1.49 \mathrm{ENZ}+1.16(\mathrm{ENZ} \times \mathrm{ENZ})+0.167 \mathrm{CP} 0.85 & 0.013 & 0.017 \\ \mathrm{DNDF} & 0.364-2.49 \mathrm{ADL}+0.630 \mathrm{ENZ}+0.622(\mathrm{NDF} \times \mathrm{NDF}) & 0.83 & 0.024 & 0.029\end{array}$

Based on calculated in vivo OM digestibility and NDF content only

\begin{tabular}{lllll} 
b & $-0.542+0.860(\mathrm{NDF} \times \mathrm{NDF})+1.66$ Sheep $^{6}$ & 0.78 & 0.031 & 0.035 \\
$\mathrm{c}$ & $0.135-1.10 \mathrm{NDF}+1.20(\mathrm{NDF} \times \mathrm{NDF})+0.210$ Sheep $^{6}$ & 0.81 & 0.014 & 0.018 \\
DNDF & $-0.380+0.784(\mathrm{NDF} \times \mathrm{NDF}) \times 1.49$ Sheep $^{6}$ & 0.79 & 0.026 & 0.030 \\
\hline
\end{tabular}

${ }^{1}$ potentially degradable part

${ }^{2}$ fractional rate of degradation $\left(\mathrm{h}^{-1}\right)$

${ }^{3} \mathrm{NDF}$ degradability after $504 \mathrm{~h}$ in situ incubation

${ }^{4}$ root mean square error

${ }^{5}$ PRESS is the prediction error in a cross-validation

${ }^{6}$ In vivo sheep digestibility of $\mathrm{OM}$ (predicted from in vitro) 


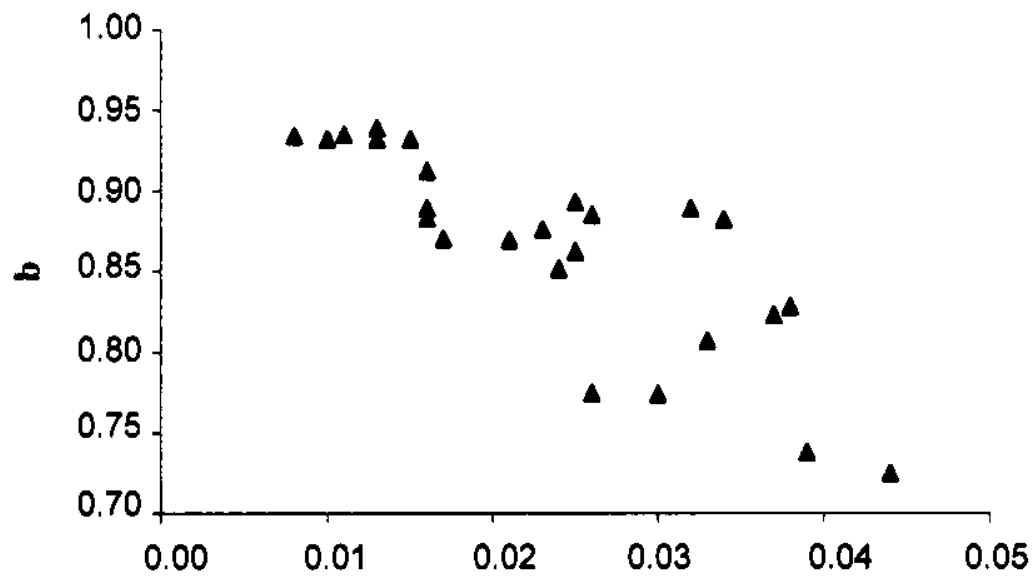

ADL, $\mathrm{kg} / \mathrm{kg}$ of DM

Figure 2. Potential degradability (b) versus ADL concentration in DM

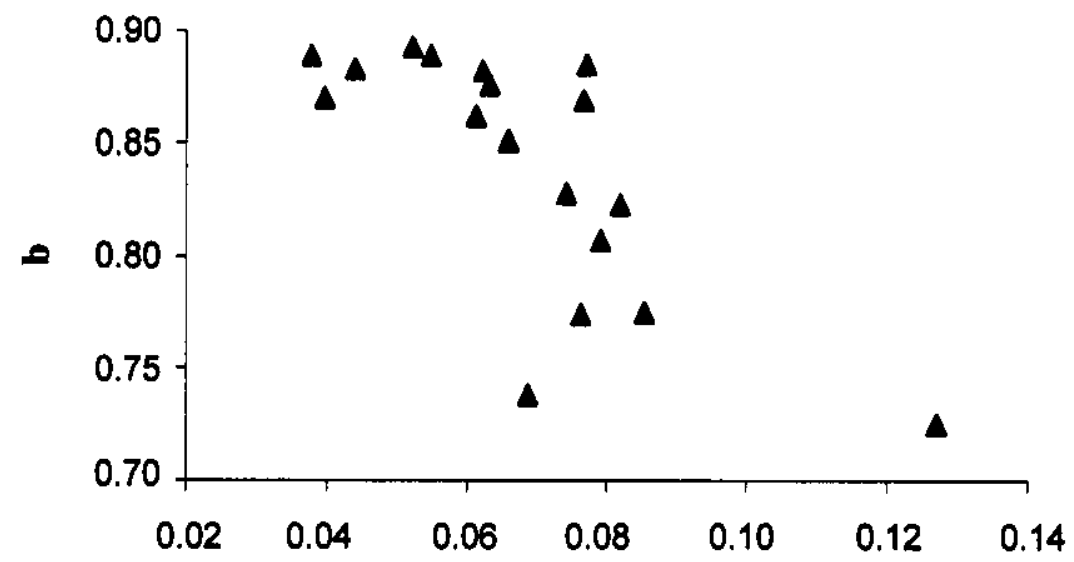

ADL, $\mathrm{kg} / \mathrm{kg}$ of NDF

Figure 3. Potential degradability (b) versus ADL proportion of NDF

Regression analyses were also performed based on only NDF content and sheep OM digestibility predicted from ENZ digestibility as NDF content and OM digestibility values are present in most feed tables. Equations based on these two measures were able to describe $0.78,0.81$ and 0.79 of the variation in $b, c$ and DNDF, respectively. 


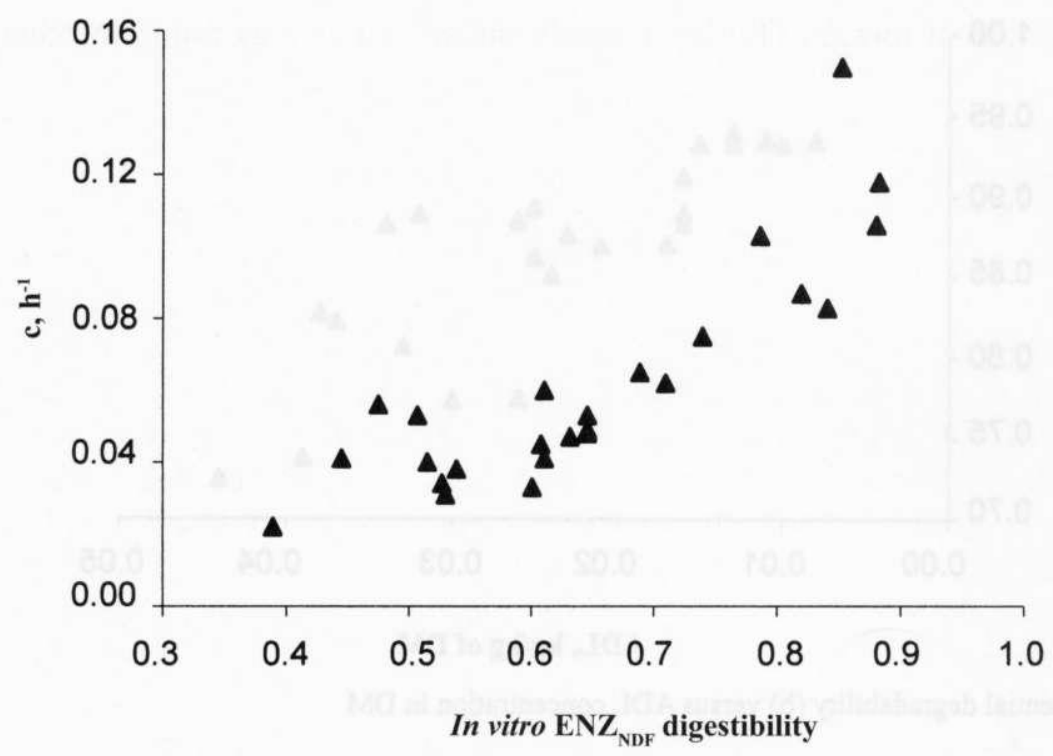

Figure 4. Fractional rate of degradation (c) versus in vitro $\mathrm{ENZ}_{\mathrm{NDF}}$ digestibility

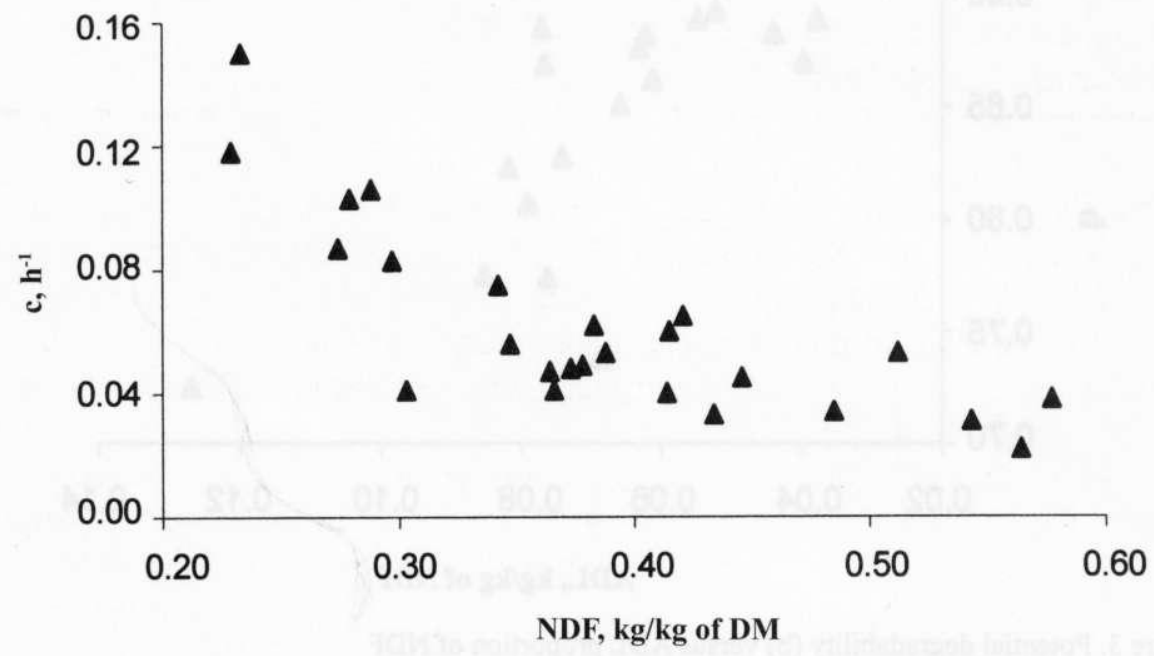

Figure 5. Fractional rate of degradation (c) versus NDF concentration in DM

\section{DISCUSSION}

The present experiment has clearly demonstrated a large variation between grass and grass/clover samples in chemical composition and in vitro digestibility of $\mathrm{OM}$ and NDF. The chemical composition (CP, NDF, ADF and ADL content) 
of the experimental forages (Table 1) was in the same range as found in other studies.

In vitro $\mathrm{OM}$ digestibility measured by the ENZ method was as a mean 0.06 higher than the in vitro digestibility measured by the $T$ and $T$ rumen fluid method. Søegaard et al. (2001) found a similar difference between the two methods. The higher values obtained with the ENZ method is probably due to the more intensive washing of the residues with hot water and acetone compared to washing with cold water in the $\mathrm{T}$ and $\mathrm{T}$ method. Opposite to this, in vitro NDF digestibility was 0.07 higher when measured by the $T$ and $T$ method than by the ENZ method, indicating a higher cellulolytic activity of the rumen fluid used in the $T$ and $T$ method compared to the enzymes used in the ENZ method. When the in vitro OM digestibility was based on the NDF residue, the modified $\mathrm{OM}$ digestibility was as a mean 0.04 higher for the $\mathrm{T}$ and $\mathrm{T}_{\text {mod }}$ compared to the $\mathrm{ENZ}_{\text {mod }}$ method, in accordance with the higher in vitro NDF digestibility for the $T$ and $T$ method.

Compared to nylon bag NDF degradabilities after $48 \mathrm{~h}$ incubations, the values obtained by the in vitro NDF methods were lower for both $T$ and $T_{X I D F}$ and $\mathrm{ENZ}_{\mathrm{NDF}}$ method, indicating lower cellulolytic activity or a larger lag time in vitro than in situ. Further, particle losses from the nylon bag during rumen incubation above initial losses might explain the higher in situ degradabilities. Despite the difference in absolute values, high correlations were found between $48 \mathrm{~h}$ NDF degradability and both OM and NDF digestibilities: i.e. ENZ $(r=0.83), T$ and T $(\mathrm{r}=0.74), \mathrm{ENZ}_{\mathrm{NDF}}(\mathrm{r}=0.86)$ and $\mathrm{T}$ and $\mathrm{T}_{\mathrm{NDF}}(\mathrm{r}=0.82)$.

There was a significant negative correlation between NDF content and digestibility of OM and NDF (Table 3). This is in accordance with other in situ and in vitro NDF digestibility studies which showed that the concentration of NDF is the major factor determining forage quality (Valentin et al., 1999; Allen, 2000 ). Increasing in vitro NDF digestibility with decreasing NDF content was also found by Weiss et al. (1992).

Predicting forage DNDF from lignin concentration has been proposed in several studies (Conrad et al., 1984; Weiss et al., 1992). Many research groups have highlighted the relationship between lignification and NDF digestibility of forages (Jung and Vogel, 1986; Buxton and Russell, 1988). In this study NDF, $\mathrm{ADF}$ and $\mathrm{ADL}$ concentrations were positively correlated. ADL content was the only fibre measure showing significant correlation with DNDF (Table 3), which is in agreement with results obtained by Traxler et al. (1998). ADL concentration was positively correlated to the lignification of NDF (ADL/NDF ratio) and negatively to the NDF digestibility (results not shown), which has also been reported previously (Van Soest, 1967; Jung and Vogel, 1986).

DNDF varied from 0.75 to 0.95 in this study. Similar variations between forages (from 0.59 to 0.90 ) in DNDF using 21 days $(504 \mathrm{~h}$ ) rumen in situ 
incubations were found by Lund (2002). With increasing maturity of ensiled or fresh grass NDF digestibility decreases. This is also obvious from this study, where potential degradability decreased from 0.895 (sample 24) to 0.776 (sample 25 ) for two silage samples from the same sward varying 3 weeks in cutting time.

The $16 \mathrm{~h}$ incubations gave lower degradabilities than expected from the degradation profile of the rest of the incubations (Figure 1). Therefore, these data were excluded from the calculations of degradation parameters. The reason for the lower $16 \mathrm{~h}$ values was probably that these samples were incubated at $16.00 \mathrm{~h}$ in the afternoon, whereas the rest of the bags were incubated at $8.00 \mathrm{~h}$ in the morning. Therefore, the results indicate that the afternoon incubation resulted in lower degradabilities than expected, probably due to lower microbial activity during the nighttime than during daytime. Incubation times up to $168 \mathrm{~h}$ resulted in underestimation of potential degradability compared to long-term incubations, as also found by Weisbjerg et al. (2001). Therefore, incubations up to $504 \mathrm{~h}$ seem necessary to determine the 'true' indigestible NDF fraction. This also means, that degradability values after $504 \mathrm{~h}$ incubation time were generally higher than expected from the other incubation times. The reason for this is probably, that fractional rate of degradation is not constant, but will decrease with increased incubation time (Van Soest, 2000). In vivo mean retention times are much lower than $504 \mathrm{~h}$, therefore the very long incubation times are less interesting to describe the in vivo situation, and $504 \mathrm{~h}$ results were deleted before calculations of degradation parameters to get an optimal fit of the results from shorter incubation times. The higher degradability than expected for $504 \mathrm{~h}$ incubations when a constant rate of degradability is assumed might partly be due to a disappearance of small particles during degradation (Van Soest, 1994).

The potentially degradable NDF fraction $b$ and the fractional rate of degradation $c$ averaged 0.865 and 0.062 per hour, respectively. Effective degradability (without lag time) of NDF varied from 0.390 to 0.805 calculated using a value of 0.02 per hour for the fractional passage rate. Including lag time for ED calculations resulted only in small changes, and the parameters obtained from the model without lag time was therefore used for the regression analysis.

The potentially degradable fraction $b$ was highly correlated to ADL content and ADL/NDF ratio whereas the fractional rate of degradation c mainly was correlated to in vitro digestibilities (Table 3 ), especially $\mathrm{ENZ}_{\mathrm{NDF}}$ was highly correlated to $\mathrm{c}$. This indicates, that a direct determination of NDF digestibility is necessary to get a high correlation with $\mathrm{c}$. A possible option, if only OM digestibility is measured, is then to estimate in vivo NDF digestibility based on the Lucas principle as proposed by Weisbjerg et al. (2004).

Digestion in the rumen is a time dependent dynamic process and the result of a competition between the fractional rate of digestion in the rumen and the fractional rate at which feed components pass out of the rumen (Waldo et al., 1972). As the rumen degradation is a dynamic process, the effective rumen degradation is highly 
affected by the fractional passage rate and will therefore depend on, for example, feeding level. Effective degradabilities presented in Table 2 are calculated at a fractional passage rate of 0.02 per hour using a simple one-pool rumen model. This model do not take into account the selective retention in the rumen of newly ingested NDF, and therefore the obtained values probably underestimate in vivo digestibility and should only be regarded as a ranking of the forages.

The aim of the present study was to present prediction equations for the NDF degradation parameters. Three sets of equations are presented (Table 4). For all three sets the stepwise procedure in SAS (SAS Institute, 2000) was used to find the best equations. The first set was based on all available measures in this study. However, as all these analyses will seldom be available, a second set of equations was based on in vitro OM digestibility and chemical analysis. The third set of equations was based on NDF concentration and predicted in vivo sheep OM digestibility which is information available in most feedstuff tables.

With the increasing restriction on prediction parameters used, the explanation ability of the equations $\left(\mathrm{R}^{2}\right)$ decreased with approximately 0.10 . Even with the third set of equations the $\mathrm{R}^{2}$ for the prediction equations for the different degradation parameters were approximately 0.80 . This shows that it is possible to describe most of the variation in NDF degradation parameters using common feed analyses. Compared to this study with grass and grass/clover, similar studies on whole crop cereals showed poorer correlations between NDF degradation parameters and chemical composition and in vitro digestibilities (Weisbjerg et al., 2003).

Multiple regression analysis can be questioned, as they can result in parameters without biological sense. An example on this is the positive parameter values for ADF concentration and lignification (ADL in proportion of NDF) found in some of the equations in Table 4. These unbiological parameter values are probably due to the strong correlation between in vitro digestibility and lignification. Therefore, the two first sets of equations should rather be regarded as the potential for explanation than a proposal for equations for practical use. The third set of equations is based on only NDF concentration and OM digestibility, analysis that are commonly performed as standard on feed samples from practice. These equations can therefore be used in practice on forage samples believed to be covered by the sample population examined in this study. However, extrapolation of the equations to be used on samples from other populations (forage types, climatic regions) needs further examinations. The single analysis that showed the highest correlation with fractional rate of degradation (c) was $\mathrm{ENZ}_{\mathrm{NDF}}$, and for potential NDF degradability (b and DNDF) ADL concentration and ADL in proportion of NDF showed a high correlation (Table 3 ). Therefore predictions using simple linear regressions could also be an option.

The degradation parameters, which we try to estimate from laboratory methods, are not directly measured values, but are estimated from the degradation 
profile using the PROC NLIN (SAS, 2000). The PROC NLIN simultaneously estimate fractional rate of degradation (c) and potential degradability (b), and these estimates are normally highly correlated. Therefore, each of the parameters can have a high error on the prediction, although they as a set of parameters are well estimated. Due to the possible high error on the original prediction of the individual parameters ( $c$ and $b$ ), the prediction of the parameter estimates using alternative methods/measures like in this study, cannot be expected to give very low prediction errors, and therefore the explanation obtained in this study is satisfactory. This also underlines, that degradation parameters should always be regarded as a set of parameters, not as individual parameters.

\section{CONCLUSIONS}

The present study showed that common laboratory analyses could be used for prediction of both potential degradability and rate of degradation of NDF for grass/clover forages.

\section{ACKNOWLEDGEMENTS}

The authors express their thank to Edith Olsen, Ejner Serup, Hanne Pedersen, Inger Østergaard and Kirsten Nielsen from The Danish Institute of Agricultural Sciences for their valuable advice and skilful technical and laboratory support.

\section{REFERENCES}

Allen M.S., 2000. Effects of diet on short-term regulation of feed intake by lactating dairy cows. J. Dairy Sci. 83, 1598-1624

Allen M.S., Mertens D.R., 1988. Evaluating constraints on fiber digestion by rumen microbes. J. Nutr. 118, 261-270

Anonymous, 1998. Method for Determining Neutral Detergent Fiber (aNDF). Ankom Technology, USA, pp. 2

AOAC, 1990. Official Methods of Analysis, Association of Official Analytical Chemists. $15^{\text {th }}$ Edition. Washington, DC

Besle J.M., Cornu A., Jouany J. P., 1994. Roles of structural phenylpropanois in forage cell wall digestion. J. Sci. Food Agr. 64, 171-190

Buxton D.R., Russell J.R., 1988. Lignin constituents and cell-wall digestibility of grass and legume stems. Crop Sci. 28, 553-558

Conrad H.R., Weis W.P., Odwongo W.O., Shockey W.L., 1984. Estimating net energy lactation from components of cell solubles and cell walls. J. Dairy Sci. 67, 427-436

Ellis W.C., Poppi D.P., Matis J.H., Lippke H., Hill T.M., Rouquette F.M., 1999. Dietary digestivemetabolic interactions determining the nutritive potential of ruminants diets. In: H.J.G. Jung, 
G.C. Fahey Jr. (Editors). Nutrition and Ecology of Herbivores. Proceedings of $5^{\text {th }}$ International Symposium on the Nutrition of Herbivores, San Antonio. Amer. Soc. Anim. Sci., Savoy, IL. pp. 423-481

Ferreira A.M., Kerstens J., Gast C.H., 1983. The study of several modifications of the neutral detergent fibre procedure. Anim. Feed Sci. Tech. 9, 19-28

Hvelplund T., Weisbjerg M.R., 2000. In situ techniques for the estimation of protein degradability and postrumen availability. In: D.I. Givens, E. Owen, R.F.E. Axford, H.M. Omed (Editors). Forage Evaluation in Ruminant Nutrition. CABI Publishing, pp. 233-258

Jung G., Vogel K.P., 1986. Influence of lignin on digestibility of forage cell wall material. J. Anim. Sci. $62,1703-1712$

Lund P., 2002. The effect of forage type on passage kinetics and digestibility of fibre in dairy cows. Ph.D. Thesis. The Royal Veterinary and Agricultural University, Copenhagen (Denmark), pp. 171

Madsen J., Hvelplund T., 1994. Prediction of in situ protein degradability in the rumen: results of a European ring test. Livest. Prod. Sci. 39, 201-212

McDonald 1., 1981. A revised model for the estimation of protein degradability in the rumen. J. Agr. Sci. 96, 251-252

Mertens D.R., 1993. Kinetics of cell wall digestion and passage in ruminants. In: H.G. Jung, D.R. Buxton, R.D. Hatfield, J. Ralph (Editors). Forage Cell Wall Structure and Digestibility. American Society of Agronomy, pp. 535-570

Mertens D.R., 1994. Regulation of feed intake. In: G.C. Fahey, J.M. Collins, D.R. Mertens, L.E. Moser (Editors). Forage Quality, Evaluation and Utilization. American Society of Agronomy, Crop Science Society of America, Soil Science Society of America, Madison, WI, pp. 450-493

Ørskov E.R., McDonald I., 1979. The estimation of protein degradability in the rumen from incubation measurements weighted according to rate of passage. J. Agr. Sci. 92, 499-503

SAS Institute, 2000. SAS/STAT. User's Guide, ver. 8, Vol. 1, 2 and 3. SAS Institute Inc., Cary, NC (USA), pp. 3884

Søegaard K., Weisbjerg M.R., Thøgersen R., Mikkelsen M., 2001. Laboratory methods for estimation of digestibility in forages for cattle, focussing on starch rich whole crop cereals (in Danish). Forskningsrapport No. 34. Denmarks Jordbruks Forshning (Denmark), pp. 28

Stensig T., Robinson P.H., 1997. Digestion of passage kinetics of forage fiber in dairy cows as affected by fiber-free concentrate in the diet. J. Dairy Sci. 80, 1339-1352

Tilley J.M.A., Terry R.A., 1963. A two stage technique for the in vitro digestion of forages. J. Brit. Grassl. Soc. 18, 104-111

Traxler M.J., Fox D.G., Van Soest P.J., Pell A.N., Lascano C.E., Lanna D.P.D., Moore J.E., Lana R.P., Vélez M., Flores A., 1998. Predicting forage indigestible NDF from lignin concentration. J. Anim. Sci. 76, 1469-1480

Valentin S.F., Forbes J.M., Lescoat P., 1999. Comparison of voluntary intake by lactating cows of two maize silages with different in situ dry matter degradability. Ann. Zootech. 48, 211-218

Van Soest P.J., 1967. Development of a comprehensive system of feed analyses and its application to forages. J. Anim. Sci. 26, 119-128

Van Soest P.J., 1994. Nutritional Ecology of the Ruminant. Cornell University Press, pp. 476

Van Soest P.J., 2000. Rumen balance and rates of fiber digestion. Proceedings of Cornell Nutrition Conference, pp. 150-166

Van Soest P.J., Robertson J.B., Lewis B.A., 1991. Methods for dietary fiber, neutral detergent fiber, and nonstarch polysaccharides in relation to animal nutrition. J. Dairy Sci. 74, 3583-3597

Waldo D.R., 1986. Effect of forage quality on intake and forage-concentrate interactions. J. Dairy Sci. 69, 617-631 
Waldo D.R., Smith W., Cox E.L., 1972. Model of cellulose disappearance from the rumen. J. Dairy Sci. 55, 125-129

Weisbjerg M.R., Hvelplund T., 1993. Estimation of NE content (FUc) in straights and concentrate mixtures (in Danish). Forskningsrapport Nr. 3, Statens Husdyrbrugsforsøg, pp. 39

Weisbjerg M.R., Lund P., Hvelplund T., 2001, Effect of supplementation on rate of neutral detergent fiber degradation in forages measured in situ and by rumen evacuation. J. Dairy Sci. 79, Suppl. 1,421

Weisbjerg M.R., Mikkelsen M., Bossen D., Lund P., 2003. Estimation of potential degradability and rate of degradation of NDF from barley and wheat whole crop. In: T.H. Garmo (Editor). Early Harvested Forage in Milk and Meat Production. Proceedings of the Symposium. Kringler, Nannestad (Norway), pp. 114-116

Weisbjerg M.R., Hvelplund T., Søegaard K., 2004. Prediction of NDF digestibility based on assumptions about true digestibility and endogenous loss of NDS. J. Anim. Feed Sci. 13, Suppl. $1,243-246$

Weiss W.P., Conrad H.R., St. Pierre N.R., 1992. A theoretically-based model for predicting total digestible nutrient values of forages and concentrates. Anim. Feed Sci. Tech. 39, 95-110

\section{STRESZCZENIE}

\section{Ocena rozkladu NDF traw i mieszanki trawy/koniczyna na podstawie metod laboratoryjnych}

Oznaczono rozkład włókna NDF typowych duńskich zielonek ( 25 prób traw i mieszanki trawy/ koniczyna) stosując inkubację woreczków nylonowych w żwaczu.

Strawność substancji organicznej (SO) in vitro oznaczono dwiema różnymi standardowymi metodami: jedną w oparciu o metodę Tilley'a i Terry stosując płyn żwaczowy (T+T), drugą - enzymatyczną (ENZ). W paszach oznaczono zawartość NDF, ADF, ADL, popiołu i białka ogólnego (CP). Moźliwość określenia in situ potencjalnej rozkładalności NDF oraz in situ tempa rozkładalności NDF, w oparciu o strawności oznaczone in vitro oraz analizy chemiczne, badano stosując wielokrotną analizę regresji.

Stwierdzono znaczną zmienność w rozkładzie NDF pomiędzy próbami. Udział niestrawnego NDF (INDF) oznaczony po 504 godz. inkubacji in situ wynosił od 0,047 do 0,246 NDF. Tempo rozkładu NDF (c) wahało się od 0,022 do 0,150 na godz. Stwierdzono wysoką korelację pomiędzy frakcją potencjalnie rozkładalnego NDF (c) a zawartością ADL oraz stosunkiem ADL/NDF, najwyższą korelację pomiędzy tempem rozkładalności (c) a enzymatyczną in vitro strawnością NDF $\left(\mathrm{ENZ}_{\mathrm{NDF}}\right)$, a także zawartością NDF i ADL. Wyniki te wskazują, że potencjalny rozkład NDF jest głównie skorelowany z lignifikacją włókna, podczas gdy tempo rozkładu - ze strawnością.

Możliwe jest, że zmienność w potencjalnie rozkładalnej frakcji NDF (b) wynosi 0,87 , a w tempie rozkładu (c) 0,83 , jeżeli zastosuje się wszystkie dostępne dane dotyczące pasz. Na podstawie równań, opierających się na oznaczeniu in vitro strawności OM oraz wynikach analiz chemicznych, zmienność frakcji b i c wynosi odpowiednio 0,83 i 0,85 , a opartych tylko na zawartości NDF i obliczonej in vivo (na owcach) strawności OM, zmienność ta wynosi odpowiednio około $0,80 \mathrm{dla} \mathrm{b}$ i c. 